\title{
DETERMINATION OF ANTIPARKINSONISM DRUG ENTACAPONE
}

\author{
NASHWAH GADALLAH MOHAMED*AND MOHAMED SULTAN MOHAMED*
}

*National organization of drug control and research, Cairo, Egypt.

(Received: May 14, 2009 - Accepted: November 22, 2009)

\begin{abstract}
Spectrophotometric procedures are presented for the determination of the antiparkinsonism drug entacapone. The first method based on the formation of a coloured complex of entacapone with ferric chloride in ethanolic solutions. The coloured product is quantified spectrophotometrically at $665 \mathrm{~nm}$.

The other Spectrophotometric method determine entacapone in presence of levodopa and carbidopa (which formulated with entacapone in stalevo tablets) by measuring the UV absorbance of entacapone either in zero order at $391 \mathrm{~nm}$ or in the first order by measuring the amplitude between $360 \mathrm{~nm}$ and $402 \mathrm{~nm}$ without any interference from levodopa and carbidopa.

HPLC method is described for the separation and determination of entacapone, levodopa and carbidopa on Luna CN 150 x 4.6 column with UV detection at $390 \mathrm{~nm}$ for entacapone and at $280 \mathrm{~nm}$ for both levodopa and carbidopa
\end{abstract}

\section{INTRODUCTION}

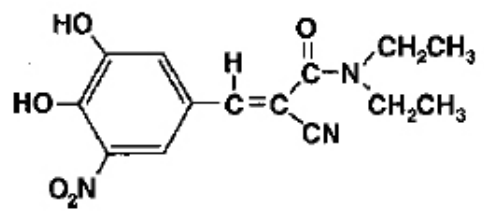

Molecular formula: $-\mathrm{C}_{14} \mathrm{H}_{15} \mathrm{~N}_{3} \mathrm{O}_{5}$

Relative molecular mass: -305.29

Chemical name: - (E)-2-cyano-3-(3,4-dihydroxy-5-nitrophenyl)-N,Ndiethyl-2-propenamide

Entacapone is a nitrocatechol structured compound. Therapeutically classified as a selective, reversible and peripheral inhibitor of catechol-Omethyl transferase. It is given as adjunctive therapy to patient with parkinson's disease. Entacapone may be given as combination preparation with carbidopa and levodopa, this will extend the effect and duration of levodopa in the brain and allows levodopa to be given less often and in lower doses ${ }^{1}$.

The reported methods for the determination of entacapone include, a column-switching LC-electrospray ionization-tandem MS method for the direct analysis of entacapone glucuronide in plasma using C18 column, and a mixture of $20 \mathrm{mM}$-ammonium acetate/acetonitrile (17:3) $\mathrm{pH} 7$ as a mobile phase $^{2}$

Two different micellar electrokinetic capillary chromatography methods were introduced for direct determination of glucuronides of entacapone and its (Z)-isomer in human urine. In the first method good separation of glucuronides was achieved with $20 \mathrm{mM}$-ammonium acetate as separation solution at $\mathrm{pH} 6.84$ ${ }^{3}$. In the second method detection was achieved at $335 \mathrm{~nm}^{4}$

Three HPLC methods for the determination of entacapone were reported, the first one determine entacapone and its Z-isomer in human plasma and urine on LiChrosorb $\mathrm{C} 18$ column fitted with a micro Bondapak C-18 guard column ${ }^{5}$. The second method determine it in plasma using internal standard rofecoxib. Separation was achieved by an isocratic mobile phase of $30 \mathrm{mM}$ phosphate buffer $(\mathrm{pH} \mathrm{2.75)/} \mathrm{acetonitrile} \mathrm{(62/38,} \mathrm{v/v).} \mathrm{The} \mathrm{used} \mathrm{column} \mathrm{was} \mathrm{a} \mathrm{reversed}$ phase $\mathrm{C} 18$ column ${ }^{6}$.

The third method detect entacapone at $305 \mathrm{~nm}^{7}$. Another HPLC method was described for the determination of the drug release of levodopa, carbidopa and entacapone from tablet formulation ${ }^{8}$.

Spectrophotometric method for the determination of entacapone in tablet was reported, the method used acetonitrile as solvent. The results were validated and compared with HPLC method ${ }^{\text {? }}$.

\section{EXPERIMENTAL}

Chemicals and reagents

Standard entacapone, levodopa and carbidopa with claimed purity 99.81 , 99.76 and 99.65 respectively. Comtapone $200 \mathrm{mg}$, Kemapharm company, batch number RD07037. Ferric chloride (ElNasr company), ethanol analytical grade (Analar), ammonium acetate (El Nasr company), and acetonitrile HPLC grade (Analar).

\section{Preparation of the reagent and mobile phase.}

1-preparation of ethanolic solution of ferric chloride $(0.4 \% \mathrm{w} / \mathrm{v})$

2 -the mobile phase was prepared by mixing $20 \mathrm{mM}$ ammonium acetate solution $\mathrm{pH} 7.5$ and acetinitrile in ratio $15: 5 \mathrm{v} / \mathrm{v}$. The mobile phase was filtered using $0.45 \mu$ nylon filters (Milipore, USA) and degassed by sonication before use.

\section{Preparation of standard solutions}

A- Stock standard solution for ferric chloride method.

An accurate weight of entacapone $(25 \mathrm{mg})$ was transferred into $100 \mathrm{ml}$ volumetric flask dissolving and raising the volume up to the mark with ethanol to produce solution of $0.25 \mathrm{mg} / \mathrm{ml}$ concentration

B-Stock standard solution for the spectrophotometric methods and HPLC method

An accurate weight $(25 \mathrm{mg})$ of entacapone was transferred into $250 \mathrm{ml}$ volumetric flask dissolving and raising the volume up to the mark with distilled water to produce solution of $0.1 \mathrm{mg} / \mathrm{ml}$ concentration.

C- Preparation of laboratory prepared mixture

Aqueous solutions of each of entacapone, levodopa and carbidopa was prepared by transferring $25 \mathrm{mg}$ of each into three separate $250 \mathrm{ml}$ volumetric flasks, dissolving and raising the volume up to the mark with distilled water to produce solution of $0.1 \mathrm{mg} / \mathrm{ml}$ concentration of each.

Into $100 \mathrm{ml}$ volumetric flask aliquots of $50 \mathrm{ml}, 37.5 \mathrm{ml}$ and $9.5 \mathrm{ml}$ of each of entacapone, levodopa and carbidopa were transferred respectively and the volume was made up using distilled water. The final concentration of the prepared mixture is similar to the concentration ratio of the mentioned drug in stalevo tablets

Apparatus

-Ultraviolet/ visible spectrophotometer shimadzu, Japan 1601 pc

-Ultrasonic crest model 575T Cortland, New York13045, USA.

-pH meter 211 Hanna, Portugal.

-HPLC instrument, Helwett Packard series 1100 equipped with quaternary pump, diod array detector, manual injector $20 \mu 1$ loop.

\section{RESULT AND DISCUSSION}

The aim of the present study was to develop simple, accurate and sensitive methods for the determination of entacapone either alone or in combination with levodopa and carbidopa which formulated with entacapone in stalevo tablets.

The first method was a colorimetric method suitable for the determination of ethanolic solution of entacapone in single form using ferric chloride.

The second method depends on measuring the UV absorbance of aqueous solution of entacapone either in zero or first order. The method was found to be suitable either for entacapone determination alone or in combination with levodopa and carbidopa. 
The third method is an accurate, simple and sensitive isocratic HPLC method for the simultaneous determination of entacapone, levodopa and carbidopa in their aqueous solution.

\section{Ferric chloride method.}

Procedure and optimization of conditions

The optimum conditions of the colored complex formation between entacapone and ferric chloride were studied including the used solvent, concentration and volume of ferric chloride solution as well as the wavelength of maximum absorbance.

Many solvents were tried including distilled water, ethanol, methanol and acetonitrile. It was found that quantitative results and complex stability were achieved on using ethanol. The optimum ferric chloride concentration and volume which gave higher sensitivity and best result reproducibility were $5 \mathrm{ml} 0.4 \% \mathrm{~W} / \mathrm{V}$ ethanolic ferric chloride solution. The spectrum of the formed complex gave maximum absorbance at $665 \mathrm{~nm} \pm 2 \mathrm{~nm}$ (Fig. 1).

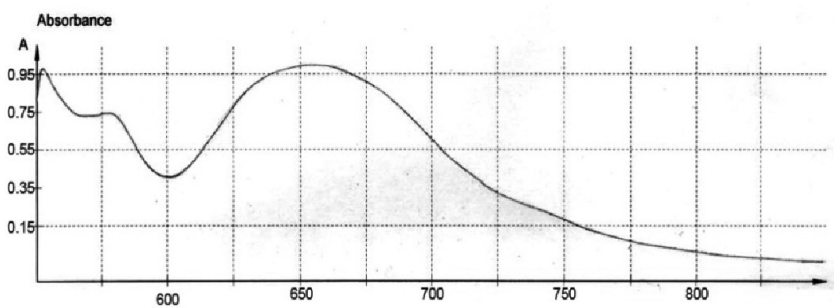

Fig. 1 Absorbance spectrum of ferric chloride- entacapone complex

\section{Linearity.}

Into a series of $10 \mathrm{ml}$ volumetric flasks transfer aliquots $(0.3-4.5 \mathrm{ml})$ of the stock standard solution prepared for ferric chloride method, to each flask $5 \mathrm{ml}$ of $0.4 \% \mathrm{w} / \mathrm{v}$ ethanolic ferric chloride solution was added. The volume was completed using ethanol. The flasks were left to stand for 5 minutes and measured spectophotometrically at $665 \mathrm{~nm}$. Each concentration was measured in triplicate. Good linearity was observed over the concentration range $10 \mu \mathrm{g} /$ $\mathrm{ml}-100 \mu \mathrm{g} / \mathrm{ml}$. The linear regression analysis data is given in table1.

Stability of the colored complex was assessed by measuring the formed complex each 10 minutes over 10 hours, the complex was found stable over 4 hours

Table 1. Results of linearity of the proposed ferric chloride method and spectrophotometric methods

\begin{tabular}{|c|c|c|c|c|}
\hline method & $\begin{array}{c}\text { Linearity } \\
\text { range } \\
(\boldsymbol{\mu g} / \mathbf{m l})\end{array}$ & intercept & slop & $\mathbf{r}^{\mathbf{2}}$ \\
\hline Ferric chloride & $10-100$ & -0.0095 & 0.0094 & 0.9994 \\
\hline $\begin{array}{c}\text { Zero order } \\
\text { spectrophotometric }\end{array}$ & $1-12$ & -0.0043 & 0.0842 & 0.9993 \\
\hline $\begin{array}{c}\text { first order } \\
\text { spectrophotometric }\end{array}$ & $2-16$ & -0.0011 & 0.0035 & 0.9992 \\
\hline
\end{tabular}

Stoichiometry

Job's method of continuous variation indicates the Fe- entacapone complex had a 1:1 stoichiometry. The complex may be formed via binding of $\mathrm{Fe}$ to the $3 \mathrm{OH}$ group which has more electron density, as the electrons at $4 \mathrm{OH}$ group are less available due to the presence of the electron withdrawing nitro group in the 5 position. The formed complex might had more complicated explanation due to the presence of more chemical species (different ions) in the solution as explained by Frank and Murry ${ }^{10}$ in the study of aluminium complexation with catechols.

\section{Spectrophotometric methods}

\section{Procedure and optimization of condition}

The reported spectrophotometric method for the determination of entacapone in acetonitrile ${ }^{9}$ is only valid for its determination in single form. The present paper introduce a simple spectrophotometric methods for entacapone determination either in single form or in combination with levodopa and carbidopa depending on the variation of of entacapone spectra on using different solvents

Entacapone shows variation in color and UV spectrum according to the solvent, acidity or alkalinity. Its methanolic or aqueous solution appears yellow with $\lambda_{\max }$ at $309 \mathrm{~nm}$ and $391 \mathrm{~nm}$ respectively. Addition of $0.1 \mathrm{~N} \mathrm{HCl}$ to an aqueous solution of entacapone turns the solution from yellow to colorless with $\lambda_{\text {max }}$ at $305 \mathrm{~nm}$, while addition of $0.1 \mathrm{NaOH}$ makes the solution red with $\lambda_{\text {max }}$ at $392 \mathrm{~nm}$ and a shoulder at $425 \mathrm{~nm}$ (fig.2).

As the catechol structure of entacapone resemble some color indicators as bromocresol green ${ }^{11}$ and phenl red ${ }^{12}$ so by studying the mechanism of color changes of these indicators, entacapone behaviour could be explained as follws:-

In water entacapone ionizes by losing one proton from on of its phenolic $\mathrm{OH}$ forming an anion, on addition of $\mathrm{NaOH}$ a second proton was lost forming dianion. The change of color and maximum wavelength of absorption between entacapone, its anion and dianion may attributed to the increase of the molecule conjugation so it absorbe lower energy (longer wavelength) ${ }^{13}$. The discharge of the yellow color on addition of $\mathrm{HCl}$ may be due to the protonization of the keto group breaking the conjugation of the molecule and makes it colorless.

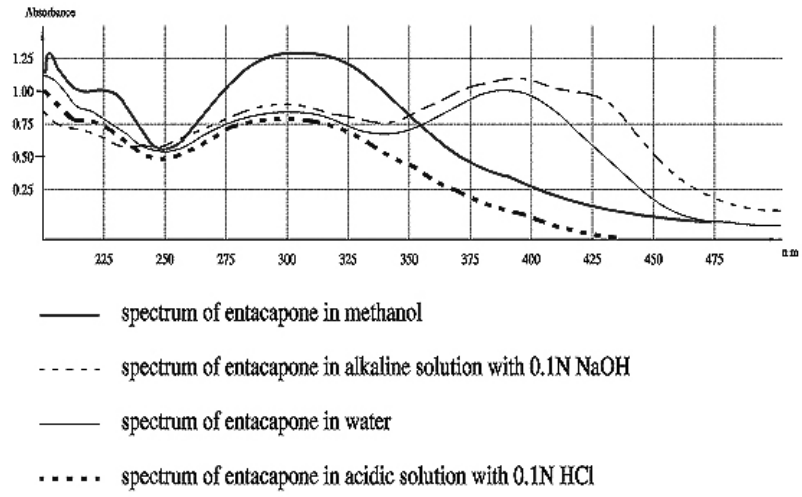

It was found that dissolving entacapone in water gives a maximum absorbance at $391 \mathrm{~nm}$ at which the drug could be measured in presence of levodopa and carbidopa without any interference, on the other hand dissolving entacapone in methanol or acetonitrile gave a $\lambda \max$ arround $306 \mathrm{~nm} \pm 3 \mathrm{~nm}$ at which levodopa and carbidopa will interfere. So distilled water was chosen as the solvent of choice for this method. The wavelength of maximum absorbance was determined by plotting the specta of aqueous entacapone solutions of different concentrations in both zero and first order. It was found that optimum wavelength of measuring entacapone in zero order is $391 \mathrm{~nm}$, while in first order it is better to measure the amplitude between $360 \mathrm{~nm}$ and $402 \mathrm{~nm}$ (Fig $3,4)$.

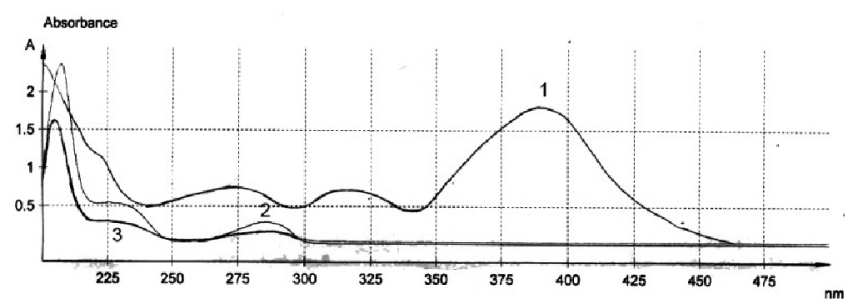

Fig.3. Zero order spectra of 1- entacapone 2- levodopa 3- carbidopa 


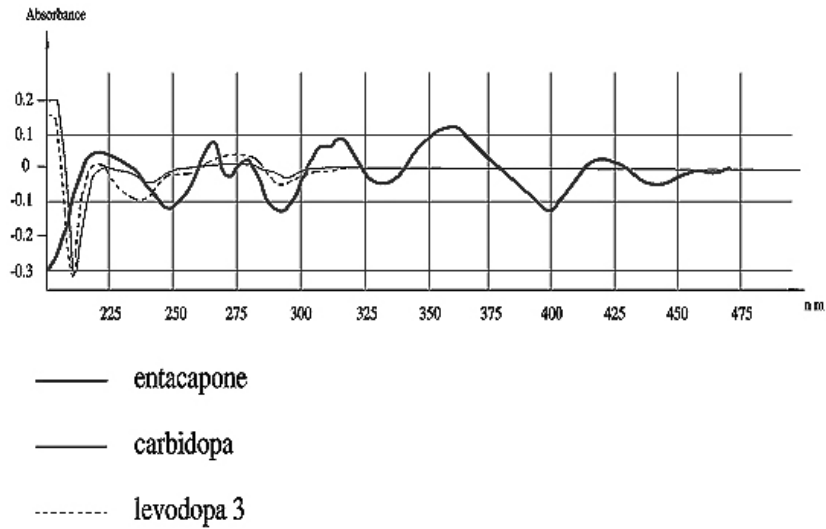

Linearity.

Into a series of $10 \mathrm{ml}$ volumetric flasks aliquots of $(0.1-2 \mathrm{ml})$ were transferred and volumes were raised up to mark using distilled water. Absorbance of each solution was measured in triplicates in zero and in first order by measuring the absorbance at $391 \mathrm{~nm}$ and the amplitude between $360 \mathrm{~nm}$ and $402 \mathrm{~nm}$ respectively. Linear relation between the concentration and absorbance was given in the range $1 \mu \mathrm{g} / \mathrm{ml}-12 \mu \mathrm{g} / \mathrm{ml}$ on using the zero order and $2 \mu \mathrm{g} / \mathrm{ml}-16 \mu \mathrm{g} / \mathrm{ml}$ on using the first order. The linear regression analysis data is given in table1

Application of the method for the determination of entacapone in mixture with levodopa and carbidopa.

Aliquots $(0.5-3 \mathrm{ml})$ of laboratory prepared mixture were transferred into a series of $10 \mathrm{ml}$ volumetric flasks, the volumes were raised up to mark with distilled water. Each solution was measured in triplicates in zero and in first order by measuring the absorbance at $391 \mathrm{~nm}$ and the amplitude between $360 \mathrm{~nm}$ and $401 \mathrm{~nm}$ respectively. Good results were obtained as shown in table 2.

Table 2. Results of analysis of laboratory prepared mixture using the proposed spectrophotometric and HPLC methods.

\begin{tabular}{|c|c|c|c|c|c|c|c|c|c|}
\hline \multirow[b]{2}{*}{ drug } & \multicolumn{3}{|c|}{ Zero order method } & \multicolumn{3}{|c|}{ first order method } & \multicolumn{3}{|c|}{ HPLC method } \\
\hline & $\begin{array}{l}\text { Taken } \\
(\mu \mathrm{g} / \mathrm{ml})\end{array}$ & $\begin{array}{l}\text { Found } \\
(\mu \mathrm{g} / \mathrm{ml})\end{array}$ & $\begin{array}{l}\% \\
\text { recovery }\end{array}$ & $\begin{array}{l}\text { Taken } \\
(\mu \mathrm{g} / \mathrm{ml})\end{array}$ & $\begin{array}{l}\text { Found } \\
(\mu \mathrm{g} / \mathrm{ml})\end{array}$ & $\begin{array}{l}\% \\
\text { recovery }\end{array}$ & $\begin{array}{l}\text { Taken } \\
(\mu \mathrm{g} / \mathrm{ml})\end{array}$ & $\begin{array}{l}\text { Found } \\
(\mu \mathrm{g} / \mathrm{ml})\end{array}$ & $\begin{array}{l}\% \\
\text { recovery }\end{array}$ \\
\hline $\begin{array}{l}\text { Entacapone } \\
\text { mean } \pm \text { SD }\end{array}$ & $\begin{array}{l}2.5 \\
5 \\
7.5 \\
10\end{array}$ & $\begin{array}{l}2.545 \\
4.897 \\
7.55 \\
9.99\end{array}$ & $\begin{array}{l}101.81 \\
97.90 \\
100.67 \\
99.90 \\
100.07 \pm 1.65\end{array}$ & $\begin{array}{l}5 \\
7.5 \\
10 \\
15\end{array}$ & $\begin{array}{l}4.89 \\
7.48 \\
10.03 \\
14.89\end{array}$ & $\begin{array}{l}97.80 \\
99.50 \\
100.30 \\
99.30 \\
99.23 \pm 1.04\end{array}$ & $\begin{array}{l}10 \\
30 \\
40 \\
47.5\end{array}$ & $\begin{array}{l}10.11 \\
30.19 \\
39.99 \\
47.52\end{array}$ & $\begin{array}{l}101.10 \\
100.64 \\
99.97 \\
100.04 \\
100.44 \pm 0.53\end{array}$ \\
\hline $\begin{array}{l}\text { Levodopa } \\
\operatorname{mean} \pm \mathrm{SD}\end{array}$ & $\begin{array}{l}1.875 \\
3.750 \\
5.625 \\
7.500\end{array}$ & $\begin{array}{l}- \\
- \\
- \\
-\end{array}$ & $\begin{array}{l}- \\
- \\
- \\
-\end{array}$ & $\begin{array}{l}3.750 \\
5.625 \\
7.500 \\
11.25\end{array}$ & $\begin{array}{l}- \\
- \\
- \\
-\end{array}$ & $\begin{array}{l}- \\
- \\
- \\
-\end{array}$ & $\begin{array}{l}7.5 \\
22.5 \\
30 \\
35.625\end{array}$ & $\begin{array}{l}7.55 \\
22.16 \\
30.11 \\
35.85\end{array}$ & $\begin{array}{l}100.66 \\
98.51 \\
100.38 \\
100.63 \\
100.05 \pm 1.03\end{array}$ \\
\hline mean \pm SD & $\begin{array}{l}0.475 \\
0.950 \\
1.425 \\
1.900\end{array}$ & $\begin{array}{l}- \\
- \\
-\end{array}$ & $\begin{array}{l}- \\
- \\
-\end{array}$ & $\begin{array}{l}0.475 \\
0.950 \\
1.425 \\
1.900\end{array}$ & $\begin{array}{l}- \\
- \\
-\end{array}$ & $\begin{array}{l}- \\
- \\
- \\
-\end{array}$ & $\begin{array}{l}1.900 \\
5.700 \\
7.600 \\
9.025\end{array}$ & $\begin{array}{l}1.897 \\
5.79 \\
7.55 \\
9.023\end{array}$ & $\begin{array}{l}99.82 \\
101.58 \\
99.37 \\
99.98 \\
100.19 \pm 0.96\end{array}$ \\
\hline
\end{tabular}

\section{HPLC method.}

\section{Procedure and optimization of conditions}

The repoted HPLC method ${ }^{8}$ concerned with the determination of the percent drug release of levodopa, carbidopa and entacapone from its combination dosage form. The present work introduce a HPLC method for the determination of each of entacapone levodopa or carbidopa in its aqueous solution or thier simultaneous determination in laboratory prepared mixture making the method convenient for quality control determiation of formulations containing one or more substances of the studied drugs.
Optmization of the chromatographic conditions were carefully tested. Initially various mobile phases and stationery phases were tested to obtain the best separation and resolution between entacapone, levodopa and carbidopa, which were obtained on using Luna CN 150x4.6 mm column as a stationery phase and $20 \mathrm{mM}$ ammonium acetate solution $\mathrm{pH} 7.5$ and acetonitrile $15: 5$ as a mobile phase at flow rate $1 \mathrm{ml} / \mathrm{min}$ and detection was carried out at $390 \mathrm{~nm}$ for entacapone and 280nm for both levodopa and carbidopa Fig 5,6. 


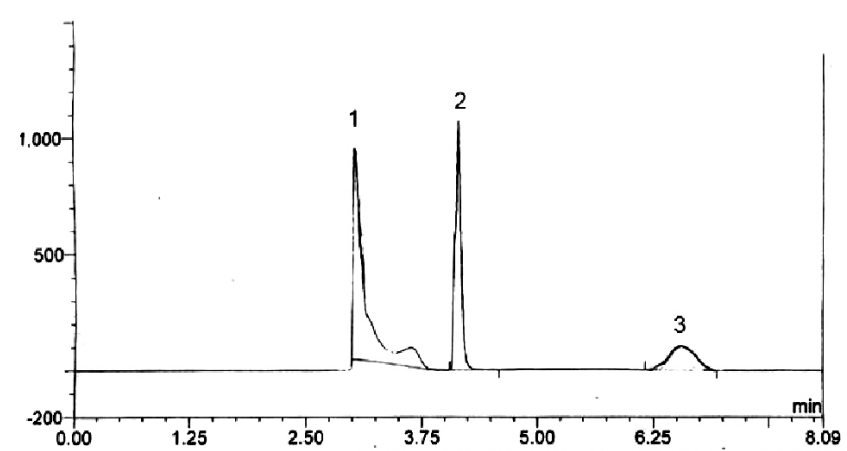

Fig. 5. HPLC chromatogram of 1-entacapone 2- levodopa 3- carbidopa at $280 \mathrm{~nm}$

\section{Linearity}

From the stock standard solution $0.1 \mathrm{mg} / \mathrm{ml}$ in distilled water of each of entacapone, levodopa and carbidopa, $50,37.5 \mathrm{ml}$ and $9.5 \mathrm{ml}$ respectively were transferred into three separate $100 \mathrm{ml}$ volumetric flasks and the volumes were made up with distilled water. From these solutions aliquots $(0.5-24 \mathrm{ml})$ of each drug were transferred into $25 \mathrm{ml}$ volumetric flasks and the volumes were raised to the mark using distilled water. Each flask was measured in triplicate using the mentioned optimum conditions. Results indicated linear relation between the concentration and the peak area within the range $1 \mu \mathrm{g} / \mathrm{ml}-48 \mu \mathrm{g} / \mathrm{ml}$ of entacapone, $1.5 \mu \mathrm{g} / \mathrm{ml}-36 \mu \mathrm{g} / \mathrm{ml}$ for levodopa and $0.76 \mu \mathrm{g} / \mathrm{ml}-9.12 \mu \mathrm{g} / \mathrm{ml}$ for carbidopa. The linear regression analysis data is given in table3

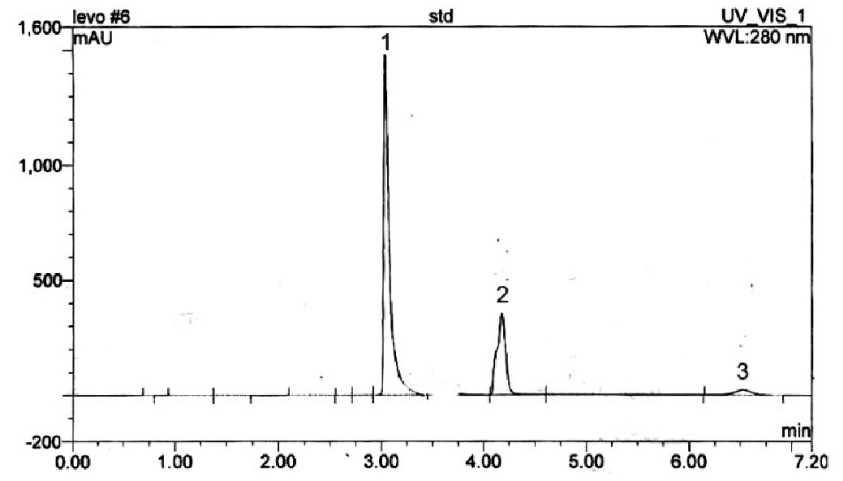

Fig. 6. HPLC chromatogram of 1-entacapone 2- levodopa 3- carbidopa at $390 \mathrm{~nm}$

Table 3. Results of linearity of the proposed HPLC method

\begin{tabular}{|c|c|c|c|c|}
\hline drug & $\begin{array}{c}\text { Linearity } \\
\text { range } \\
(\boldsymbol{\mu g} / \mathbf{m l})\end{array}$ & intercept & slop & $\mathbf{r}^{2}$ \\
\hline entacapone & $1-48$ & -2.6629 & 165.37 & 0.9999 \\
\hline levodopa & $1.5-36$ & 5.1292 & 170.85 & 0.9999 \\
\hline carbidopa & $0.76-9.12$ & -0.6875 & 175.41 & 0.9995 \\
\hline
\end{tabular}

Application of the method for the simultaneous determination of entacapone, levodopa and carbidopa.

Aliquots $(2.0-9.5 \mathrm{ml})$ of laboratory prepared mixture were transferred into a series of $10 \mathrm{ml}$ volumetric flasks, volumes were raised up with distilled water. Each solution was injected in triplicate using the mentioned optimum chromatographic conditions, results are illustrated in table 2.

\section{Accuracy}

The accuracy of the three methods was tested for the determination of different concentrations of entacapone either alone or in mixture with levodopa and carbidopa. Recovery range and standard deviation are given in table 4, 5.

Table 4. Accuracy of ferric chloride method and spectrophotometric methods.

\begin{tabular}{|c|c|c|c|c|c|c|c|c|}
\hline \multicolumn{3}{|c|}{ Ferric chloride method } & \multicolumn{3}{|c|}{ Zero order method } & \multicolumn{3}{|c|}{ First order method } \\
\hline $\begin{array}{l}\text { Taken } \\
(\mu \mathrm{g} / \mathrm{ml})\end{array}$ & $\begin{array}{l}\text { Found } \\
(\mu \mathrm{g} / \mathrm{ml})\end{array}$ & $\begin{array}{l}\% \\
\text { recovery }\end{array}$ & $\begin{array}{l}\text { Taken } \\
(\mu \mathrm{g} / \mathrm{ml})\end{array}$ & $\begin{array}{l}\text { Found } \\
(\mu \mathrm{g} / \mathrm{ml})\end{array}$ & $\begin{array}{l}\% \\
\text { recovery }\end{array}$ & $\begin{array}{l}\text { Taken } \\
(\mu \mathrm{g} / \mathrm{ml})\end{array}$ & $\begin{array}{l}\text { Found } \\
(\mu \mathrm{g} / \mathrm{ml})\end{array}$ & $\begin{array}{l}\% \\
\text { recovery }\end{array}$ \\
\hline $\begin{array}{l}15 \\
30 \\
60 \\
90 \\
\text { mean } \pm \mathrm{SD}\end{array}$ & $\begin{array}{l}14.84 \\
30.48 \\
60.48 \\
89.95\end{array}$ & $\begin{array}{l}98.94 \\
101.60 \\
100.80 \\
99.94 \\
100.32 \pm 1.143\end{array}$ & $\begin{array}{l}3 \\
6 \\
9 \\
12\end{array}$ & $\begin{array}{l}3.02 \\
5.99 \\
9.15 \\
11.9\end{array}$ & $\begin{array}{l}100.67 \\
99.83 \\
101.65 \\
99.20 \\
100.34 \pm 1.062\end{array}$ & $\begin{array}{l}6 \\
9 \\
12 \\
15\end{array}$ & $\begin{array}{l}6.029 \\
9.170 \\
12.030 \\
14.886\end{array}$ & $\begin{array}{l}100.45 \\
101.90 \\
100.24 \\
99.24 \\
100.46 \pm 1.097\end{array}$ \\
\hline
\end{tabular}

Table 5. Accuracy of HPLC method.

\begin{tabular}{|c|c|c|c|c|c|c|c|c|}
\hline \multicolumn{3}{|c|}{ Entacapone } & \multicolumn{3}{|c|}{ Levodopa } & \multicolumn{3}{|c|}{ carbidopa } \\
\hline $\begin{array}{l}\text { Taken } \\
(\mu \mathrm{g} / \mathrm{ml})\end{array}$ & $\begin{array}{l}\text { Found } \\
(\mu \mathrm{g} / \mathrm{ml})\end{array}$ & $\begin{array}{l}\% \\
\text { recovery }\end{array}$ & $\begin{array}{l}\text { Taken } \\
(\mu \mathrm{g} / \mathrm{ml})\end{array}$ & $\begin{array}{l}\text { Found } \\
(\mu \mathrm{g} / \mathrm{ml})\end{array}$ & $\begin{array}{l}\% \\
\text { recovery }\end{array}$ & $\begin{array}{l}\text { Taken } \\
(\mu \mathrm{g} / \mathrm{ml})\end{array}$ & $\begin{array}{l}\text { Found } \\
(\mu \mathrm{g} / \mathrm{ml})\end{array}$ & $\begin{array}{l}\% \\
\text { recovery }\end{array}$ \\
\hline $\begin{array}{l}6 \\
12 \\
24 \\
48 \\
\text { mean } \pm \text { SD }\end{array}$ & $\begin{array}{l}6.033 \\
11.950 \\
23.810 \\
48.380\end{array}$ & $\begin{array}{l}100.55 \\
99.58 \\
99.21 \\
100.8 \\
100.035 \pm 0.76\end{array}$ & $\begin{array}{l}4 \\
8 \\
16 \\
32\end{array}$ & $\begin{array}{l}3.97 \\
8.08 \\
15.92 \\
32.2\end{array}$ & $\begin{array}{l}99.25 \\
101.00 \\
99.50 \\
100.64 \\
100.1 \pm 0.853\end{array}$ & $\begin{array}{l}1 \\
2 \\
4 \\
6\end{array}$ & $\begin{array}{l}1.01 \\
2.01 \\
3.97 \\
6.03\end{array}$ & $\begin{array}{l}101.00 \\
100.50 \\
99.34 \\
100.50 \\
100.335 \pm 0.704\end{array}$ \\
\hline
\end{tabular}

Application of the proposed methods on pharmaceutical preparation

Entacapone in comet tablet was determined using ferric chloride method, spectrophotometric methods and HPLC method. Results show good agreement between found and claimed amount of entacapone as shown in table 6 , confirming the suitability of the proposed methods for the quality control determination of entacapone in pharmaceutical formulation. The validity of the methods was assessed applying the standard addition technique, results are given in table, 7,8 . 
Table 6. Determination of entacapone in comptan tablets using the proposed methods.

\begin{tabular}{|c|c|c|c|c|c|c|c|c|c|c|c|}
\hline \multicolumn{3}{|c|}{ Ferric chloride method } & \multicolumn{3}{|c|}{ Zero order method } & \multicolumn{3}{|c|}{ First order method } & \multicolumn{3}{|c|}{ HPLC method } \\
\hline $\begin{array}{c}20 \\
40 \\
60 \\
\text { mean } \pm \text { SD }\end{array}$ & $\begin{array}{l}20.37 \\
39.63 \\
60.16\end{array}$ & $\begin{array}{c}101.85 \\
99.10 \\
100.27 \\
100.41 \pm 1.38\end{array}$ & $\begin{array}{l}4 \\
6 \\
8\end{array}$ & $\begin{array}{l}3.95 \\
6.02 \\
8.59\end{array}$ & $\begin{array}{c}98.75 \\
100.33 \\
100.74 \\
99.94 \pm 1.05\end{array}$ & $\begin{array}{c}6 \\
8 \\
10\end{array}$ & $\begin{array}{c}6.03 \\
8.03 \\
10.03\end{array}$ & $\begin{array}{c}100.50 \\
100.38 \\
100.30 \\
100.39 \pm 0.10\end{array}$ & $\begin{array}{l}10 \\
20 \\
40\end{array}$ & $\begin{array}{c}9.90 \\
20.2 \\
40.22\end{array}$ & $\begin{array}{c}99.00 \\
101.00 \\
100.55 \\
100.18 \pm 1.05\end{array}$ \\
\hline
\end{tabular}

Table 7. Application of standard addition technique for the determination of entacapone in comptane tablets using ferric chloride method and HPLC method.

\begin{tabular}{|c|c|c|c|c|c|c|c|c|c|}
\hline \multicolumn{5}{|c|}{ Ferric chloride method } & \multicolumn{5}{|c|}{ HPLC method } \\
\hline $\begin{array}{l}\text { Taken of } \\
\text { tablets } \\
(\mu \mathrm{g} / \mathrm{ml})\end{array}$ & $\begin{array}{c}\text { Found of } \\
\text { tablets } \\
(\mu \mathrm{g} / \mathrm{ml})\end{array}$ & $\begin{array}{l}\text { Standard } \\
\text { added }(\mu \mathrm{g} / \\
\mathrm{ml})\end{array}$ & $\begin{array}{l}\text { Found } \\
\text { of added } \\
\text { standard } \\
(\mu \mathrm{g} / \mathrm{ml})\end{array}$ & $\begin{array}{c}\% \\
\text { Recovery of } \\
\text { added standard }\end{array}$ & $\begin{array}{c}\text { Taken of } \\
\text { tablets } \\
(\mu \mathrm{g} / \mathrm{ml})\end{array}$ & $\begin{array}{c}\text { Found of } \\
\text { tablets } \\
(\mu \mathrm{g} / \mathrm{ml})\end{array}$ & $\begin{array}{l}\text { Standard } \\
\text { added }(\mu \mathrm{g} / \\
\mathrm{ml})\end{array}$ & $\begin{array}{l}\text { Found } \\
\text { of added } \\
\text { standard } \\
(\mu \mathrm{g} / \mathrm{ml})\end{array}$ & $\begin{array}{c}\% \\
\text { Recovery } \\
\text { of added } \\
\text { standard }\end{array}$ \\
\hline 20 & 20.37 & $\begin{array}{l}10 \\
30\end{array}$ & $\begin{array}{c}9.90 \\
30.11\end{array}$ & $\begin{array}{c}99 \\
100.36\end{array}$ & 10 & 9.90 & $\begin{array}{c}5 \\
20\end{array}$ & $\begin{array}{c}5.05 \\
19.95\end{array}$ & $\begin{array}{c}101.00 \\
99.73\end{array}$ \\
\hline $\begin{array}{c}40 \\
\text { mean } \pm \text { SD }\end{array}$ & 39.63 & $\begin{array}{l}20 \\
60\end{array}$ & $\begin{array}{l}19.89 \\
60.74\end{array}$ & $\begin{array}{c}99.50 \\
101.20 \\
100.015 \pm 0.97\end{array}$ & 20 & 20.2 & $\begin{array}{l}15 \\
25\end{array}$ & $\begin{array}{l}14.82 \\
25.06\end{array}$ & $\begin{array}{c}98.80 \\
100.24 \\
99.94 \pm 0.92\end{array}$ \\
\hline
\end{tabular}

Table 8. Application of standard addition technique for the determination of entacapone in comptane tablets using spectrophotometric methods.

\begin{tabular}{|c|c|c|c|c|c|c|c|c|c|}
\hline \multicolumn{5}{|c|}{ Zero order method } & \multicolumn{5}{|c|}{ First order method } \\
\hline $\begin{array}{c}\text { Taken of } \\
\text { tablets } \\
(\mu \mathrm{g} / \mathrm{ml})\end{array}$ & $\begin{array}{c}\text { Found of } \\
\text { tablets } \\
(\mu \mathrm{g} / \mathrm{ml})\end{array}$ & $\begin{array}{l}\text { Standard } \\
\text { added }(\mu \mathrm{g} / \\
\mathrm{ml})\end{array}$ & $\begin{array}{l}\text { Found } \\
\text { of added } \\
\text { standard } \\
(\mu \mathrm{g} / \mathrm{ml})\end{array}$ & $\begin{array}{c}\% \\
\text { Recovery } \\
\text { of added } \\
\text { standard }\end{array}$ & $\begin{array}{c}\text { Taken of } \\
\text { tablets } \\
(\mu \mathrm{g} / \mathrm{ml})\end{array}$ & $\begin{array}{c}\text { Found of } \\
\text { tablets } \\
(\mu \mathrm{g} / \mathrm{ml})\end{array}$ & $\begin{array}{l}\text { Standard } \\
\text { added ( } \mu \mathrm{g} / \\
\mathrm{ml})\end{array}$ & $\begin{array}{l}\text { Found } \\
\text { of added } \\
\text { standard } \\
(\mu \mathrm{g} / \mathrm{ml})\end{array}$ & $\begin{array}{c}\% \\
\text { Recovery of } \\
\text { added standard }\end{array}$ \\
\hline 4 & 3.95 & $\begin{array}{l}2 \\
4\end{array}$ & $\begin{array}{l}3.03 \\
4.06\end{array}$ & $\begin{array}{l}101.37 \\
101.50\end{array}$ & 6 & 6.03 & $\begin{array}{c}6 \\
10\end{array}$ & $\begin{array}{c}5.999 \\
10.280\end{array}$ & $\begin{array}{c}99.98 \\
102.80\end{array}$ \\
\hline $\begin{array}{c}6 \\
\text { mean } \pm \text { SD }\end{array}$ & 6.02 & $\begin{array}{l}4 \\
6\end{array}$ & $\begin{array}{l}3.98 \\
5.92\end{array}$ & $\begin{array}{c}99.60 \\
98.70 \\
100.29 \pm 1.37\end{array}$ & 8 & 8.03 & $\begin{array}{l}2 \\
5\end{array}$ & $\begin{array}{l}1.999 \\
5.113\end{array}$ & $\begin{array}{c}99.93 \\
102.26 \\
101.24 \pm 1.50\end{array}$ \\
\hline
\end{tabular}

\section{REFERENCES}

1- Martendale, The Extra Pharmacopoeia $34^{\text {th }}$ edition the Royal Pharmaceutical Society, London, 1045. (2006)

2- Keski Hynnila, H.; Raanaa, K.; Taskinen, J.; Kostiainen, R.; J. Chromatogr. B. Biomed. Appl. 749(2). 253. (2000)

3- Lehtonen, P.; Lehtinen, S.; Maelkki Laine, L.; Wikberg, T.; J. Chromatogr. A. 836(1). 173. (1999)

4- Lehtonen,P.; Malkki-Laine,L.; Wikberg, T.; J. Chromatogr. B. Biomed. Appl.; 721(1). 127. (1999)

5- Karlsson,M.; Wikberg,T.; J. Pharm. Biomed. Anal. 10(8). 593. ( 1992)

6- Ramakrishna, NVS.; Vishwottam,KN.; Wishu, S.; Koteshwara, M.; Chidambara, J.; J. Chromatogr. B. Anal. Technol. Biomed. Life-Sci. 823(2). 189. (2005)
7- Paim, C.S.; Goncalves, H.M.L.; Miron, D.; Sippel, J.; Steppe, M., Chromatographia, 65. 9. (2007)

8- Ashish, S. Doshi; Kalpesh, J. Upadhyay; Tushar,N. Mehta; Nagesh Nanda; journal of AOAC international. 92(2). 394. (2009)

9- Paim, C.S.; Goncalves, H.M.L.; Lang, A.; Miron, D.; Steppe, M.; Analytical letter. 41(4). 571. (2008)

10- Frank J. Sikora and Murray B. McBride; Environ. Sci. Technol.; 23(3). 349. (1989)

11- D. Diamond, K.T. Lau, S. Brady, J. Cleary, Talanta. 75. 606. (2008)

12- Tamura, Z.; Maeda, M.; Yakugaku Zasshi. 117(10-11). 764. (1997)

13- Douglas A. Skoog, "Principles of instrumental analysis", Third edition, Sunders college publishing international edition. 186. (1985) 